\title{
Szervezeti struktúra jellemzői spanyol labdarúgó kluboknál
}

\author{
É. BÁCSNÉ BÁBA \\ Debreceni Egyetem Gazdaságtudományi Kar, bacsne.baba.eva@econ.unideb.hu
}

\begin{abstract}
Absztrakt. Hazánkban a sport szervezeti kérdései tekintetében megjelent az igény a strukturális formák letisztulására. A sport hazai fejlődése felveti azt a kérdést, hogy mely területeken tartható meg, müködhet tovább az egyesületi alapú sportmodell, illetve hol van létjogosultsága a szervezeti felépítésében is üzleti modellnek. A magyar sport gazdasági súlyának növekedése magával hozza az igényt arra, hogy mind finanszírozási, mind strukturális tekintetben egy hatékonyan múködtethető üzleti sportmodell alakuljon ki. A sport üzleti jellege különösen erôsen jelentkezik a professzionalista labdarúgásban. E sportágban világszerte jól megfigyelhetô az a strukturális átalakulási folyamat, amely a megfelelő vállalkozási forma és szerkezeti felépités elérésére irányul. E tekintetben célszerü feltérképezni a külhoni jó gyakorlatokat, hogy azok arra érdemes elemei mintaként szolgálhassanak a kialakuló magyar üzleti sportmodell esetében. Jelen cikkemben a nemzetközi élvonalba tartozó, egyesületi keretek közt múködő Real Madrid FC és Barcelona FC szervezeti struktúráját mutatom be.
\end{abstract}

Abstract. In Hungary the developement of sport sector needs to changes in structural scheme of sport organizations. The question is that, in the different sports areasthe association-based sports model, or the buisness-based sports model can operate effectively. Nowadays, in addition to professional successes in sporting activities, Hungarian sports entities and professional sports enterprises do consider options for the most effective operations possible, and gather good international practices in order to establish such business-based sports models in Hungary that are efficiently operable. The business side of sports is particularly apparent in professional football. On a global scale, this sport clearly demonstrates the process of structural transformation that is directed at the realization of the appropriate form of enterprise and structural setup. This article has been written to describe the Spanish model by example of organizational scheme of Real Madrid and Barcelona FC.

\section{Bevezetés}

A sport gazdasági szerepének növekedése az utóbbi évtizedekben vitathatatlan. A sportgazdaság elkezdett önálló ágazatként "viselkedni", amit az is bizonyít, hogy egyre nagyobb mértékű hozzájárulása az egyes államok nemzeti jövedeleméhez. Ez a tendencia -bár mértékében még elmaradva, - hazánkban is megfigyelhető.

Jelen cikkben a sportgazdaság egyik szegmensét, olyan sportvállalkozásokat vizsgálok, melyek látványcsapat sporthoz kapcsolódva folytatják sportszolgáltató tevékenységűket. A nemzetközi szinten kiemelkedő sport- és gazdasági sikerekkel jellemezhető professzionális labdarúgó klubok azért kerültek a vizsgálat fókuszába, mert a Magyarországon működő hasonló profilú sportszervezetek 
részéről megjelent az igény egymind finanszírozási, mind strukturális tekintetben hatékonyan müködtethető üzleti sportmodell kialakítására.

Az üzleti modell indokoltságát az adja, hogy az 1998. évi XXXI. törvény kimondta, hogy a nemzeti labdarúgó bajnokság első osztályában kizárólag gazdasági társasági formában működő sportszervezet indulhat[1]. Az átalakulás meg is történt, a korábban egyesületi formában múködő klubok korlátolt felelősségű társasággá, illetve részvénytársasággá alakultak át. Bár a 2004/05-ös bajnokság óta vegyes rendszerben hirdetik meg a bajnokságot -azaz gazdasági társaságok mellett ismét sportegyesületek is indulhatnak -, mégis, változatlanul valamennyi NB I-es csapat gazdasági társasági formában múködik, azaz sportvállalkozás, amelynek „üzleti” megoldásokat kell alkalmaznia.

Vizsgálatom célterülete a sportvállalkozások szervezeti struktúrája. Ebben a tekintetben is kiinduló alapként kell figyelembe venni a vállalkozások társasági formáját, hiszen az már magában meghatároz bizonyos szervezeti vonatkozásokat.

A magyar modell kialakításához célszerű a nemzetközi jó gyakorlatokat feltérképezni, hiszen a külhoni modellek számos eleme mintaként szolgálhat hazai viszonylatokban.

Korábban vizsgáltam az angol illetve a német bajnokságokban szereplő labdarúgó klubokat. Míg Angliában a „tisztán” gazdasági társasági formában működő klub az általános[2], addig Németországban megmaradt bizonyos kötödés az eredeti anyaegyesülethez. A német Ligaszövetség „50+1 szabálya” ugyanis előírja, hogy az anyaegyesületnek 50 \%-ot meghaladó mértékben "többségi részesedéssel”, azaz 50 \% + 1 szavazati többséggel kell rendelkeznie a klubja profi csapatát múködtető gazdasági társaságban[3].

Jelen vizsgálat azért irányul spanyol klubok bemutatására, mivel itt van lehetőség arra, hogy a „tisztán” egyesületi formában működtetett sportszervezetekről szerezzünk tapasztalatot.

\section{Anyag és módszer}

A vizsgálat a spanyol bajnokság, illetve a nemzetközi futball bajnokságok két kiemelkedő klubjára, az FC Barcelona-ra (23-szoros spanyolbajnok, 27-szeres spanyol kupagyőztes, 5-szörös UEFA bajnokok Ligája (BEK) győztes stb.) és a Real Madrid FC-re (32-szeres spanyol bajnok, 19-szeres spanyol kupagyőztes, 10-szeres UEFA bajnokok Ligája (BEK) győztes stb.) vonatkozik.

Az FC Barcelona egyesületi tagjainak száma: 177 246fő. Ebből:

- 43.147 nő,

- 134.099 férfi.

Ennek a tagságnak a 35\% Barcelonában, 49,5\%-a Katalóniában,14,6\%-a pedig világ különböző pontjain él.Az FC Barça-nak jelenleg 1354 szurkolói klubja (penya) van, ebből 651 Katalóniában, 612 Spanyolországban és 91 szerte a világban[4]. 


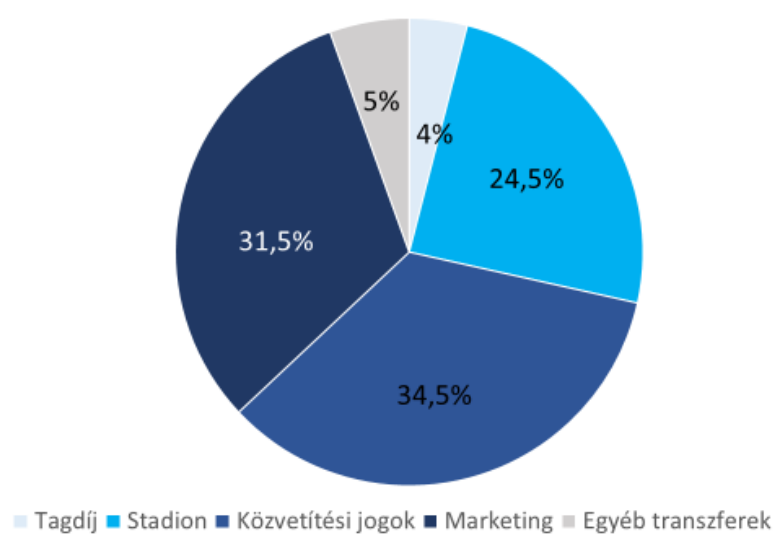

1. ábra: Az FC Barcelona árbevétele a 2014/15-ös idényben

(Forrás: [6])

Az FC Barcelona 560,8 millió Eurós bevételével a 2014/15-ös idényben a Deloitte Sports Business Group kimutatása szerint a második legeredményesebb klub a világon [5]. A Barça egy évvel korábban még a negyedik helyet foglalta el ezen a tabellán. Az 1. ábra a klub bevételeinek megoszlását mutatja be.

A Real Madrid Egyesületi tagjainak száma: 91846 fő. Ebből

- 66.671 felnőtt

- 19.797 gyermekek és

- 5.37865 évesnél idősebb, vagy már több mint 50 éve tag.

A klubnak 73.680 férfi és 18166 női tagja.

Tagdíjfizetési adatok: A klubnak

- 63.988 felnőtt tagdíj fizető $(145,49$ €.),

- 4.753 fiatal tagdíj fizető 11-14 éves (49,80 €.),

- 3.646 több, mint 65 éves, nyugdíjas, ill. már több, mint 25 éve tag, így csökkentett díjat fizető $(72,69 €$.$) ,$

- 3.386 több, mint 50 éve tag, így mentes a tagdíjfizetés alól, akárcsak

- 16.073 gyermek, aki 11 év alatti tag.

A Real Madridnak jelenleg 2311 szurkolói klubja van, ebből 2158 Spanyolországban, 153 szerte a világban (2 Magyarországon). (64 klub alakulása jelenleg folyik.) [7]

A Real Madrid már 11 éve vezeti a Deloitte által összeállított Futball "Pénzligát", a 2014/15-ös idényben 578millió Euróval[8]. Érdemes még megemlíteni, hogy az elmúlt másfél évtizedben a klub közel megötszörözte bevételeit (2. ábra). 
1999/2000.-118M

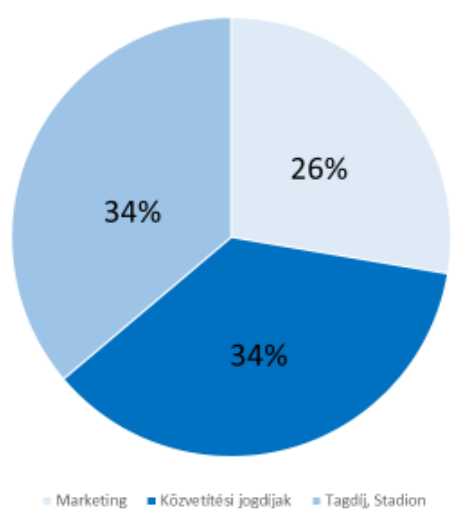

$2014 / 15-578 M$

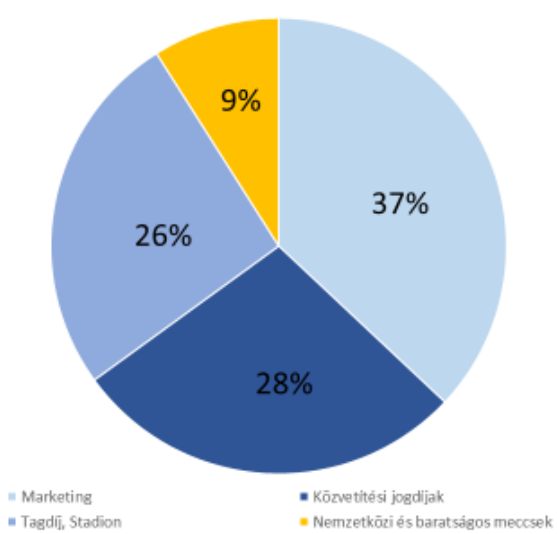

2. ábra: A Real Madrid FC bevételei az 1999/2000-e és a 2014/15-ös idényekben

(Forrás: [9]]

A vizsgálat módszere dokumentum elemzés, amely során a klubok éves beszámolóit (Annual Report), hivatalos kiadványaikat és honlapjukon megjelenő információkat tekintettem át.

\section{Az FC Barcelona jellemzése}

Az FC Barcelona jelszava: "Mes que un club!”, azaz több, mint egy klub. Ez a kijelentés alátámasztást nyer, ha a klub történelmét végiggondoljuk, hiszen a Barça a katalán kultúra, nyelv, és nemzeti érzés őrzője volt a huszadik században. Sőt, diktatórikus időkben nemcsak a nemzeti identitás, de a diktatúraellenesség és demokrácia szimbólumává is vált.

A klubra ma is jellemző a társadalmi elkötelezettség. A Barça kiáll a társadalmi, környezeti problémák felszámolásáért, a gyermekek helyzetének javításáért (2006. UNICEF megállapodás). Számtalan kulturális, szociális, karitatív kezdeményezés köthető a klubhoz, melynek alapítványa világszerte jótékonykodik.

Az FC Barcelona egyesület formájában létezik. Amint az 1. ábrán látható a tagdíjak csupán a bevételek 4\%-t teszik ki, mégisa tagok minden fontosabb döntésbe beleszólhatnak. Az természetes, hogy az egyesület elnökét, illetve az igazgatóságot szavazással választják meg, de minden más döntési folyamatba is résztveszhetnek, részt vesznek. Az egyik legutóbbi nagy horderejű döntést is a klubtagok hozták meg egy “football-népszavazáson”, a Nou Camp Stadion sorsáról. Az "Espai Barça” projektet 2014. április 4-én szavazták meg a pártoló tagok, 72,36\%-os többséggel. A projekt tartalmazza a Camp Nou modernizációját, az új Palau Blaugrana és az új Miniestadi megépítését, illetve a velük kapcsolatos területek rekonstrukcióját[10].

A demokratikus irányítást[11] mutatja, hogy ebben a 600 millió Eurós költségvetésű projektben is a tagok akarata döntött. 
Az igazgatóság kiválasztásakor megfigyelhető, hogy ahelyi kötődésű szakemberek kerülnek a vezető posztokra[12]. Ezt a gyakorlatot az a klub tapasztalat indokolja, hogy a házon belülről kinevezett vezetők hatékonyabban működtetik a szervezetet.

A sportstratégiában is hasonló elvet követnek. Eszerint nem feltétlenül sztárjátékosok vásárlása vezet a sportsikerhez, nagyobb jelentősége van a csapatépítésnek, az utánpótlás-nevelésnek. Egy spanyol kutatás az 1999-2009 közti évtizedet vizsgálva megállapította, hogy míg ebben az időszakban a Real Madrid 40 játékos megvásárlására 735 millió Eurót költött, addig a Barcelona 365 millióért vet 35 játékost, miközben a csapatban játszott a saját nevelésű Xavi, Iniesta, Messi, Busquets, Valdes[13].

A klubot müködtető elnökség felépítését vizsgálva megállapítható, hogy az funkcionális elveket mutat(3. ábra).A fontosabb feladatokat egy-egy, az adott területre specializálódott szakember irányítja. Az általános igazgatóság égisze alatt múködik a klub titkár, a klub jogász, a protokoll igazgató, és az FCB Alapítvány vezetése (az ábrán bordó színnel jelölve). A kommunikációnak, a sportterületnek, a múködtetésnek, a kereskedelmi ügyeknek, a társadalmi értékek képviseletének és az Espai Barça Projektnek önálló irányítása van. A belső ellenőrzés valamennyi terület felügyeletét ellátja. Az igazgatóságot, mint testületet, az elnök vezetésével ezen területek igazgatói alkotják.

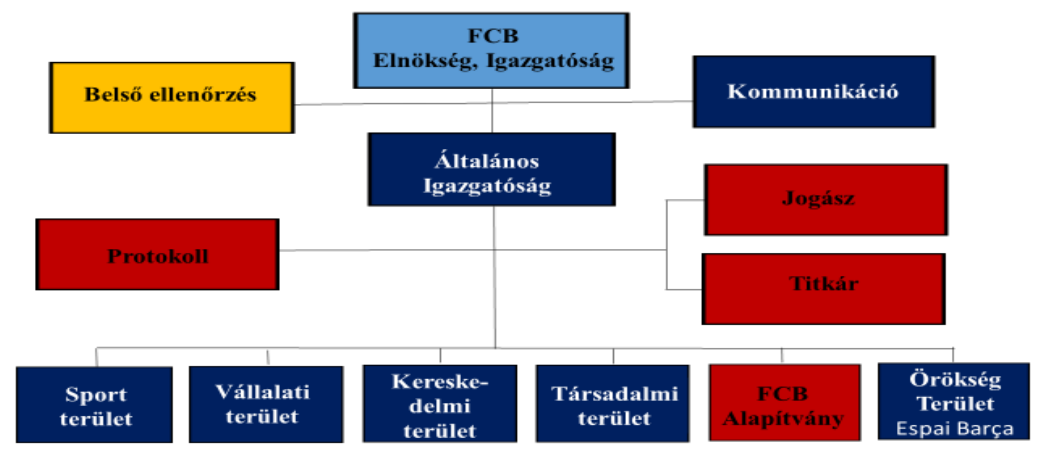

3. ábra: Az FCB Elnökségének, igazgatóságának felépítése

(Forrás: [14])

Az igazgatóság utasításait végrehajtó szervezet felépítését a 4. ábra mutatja.

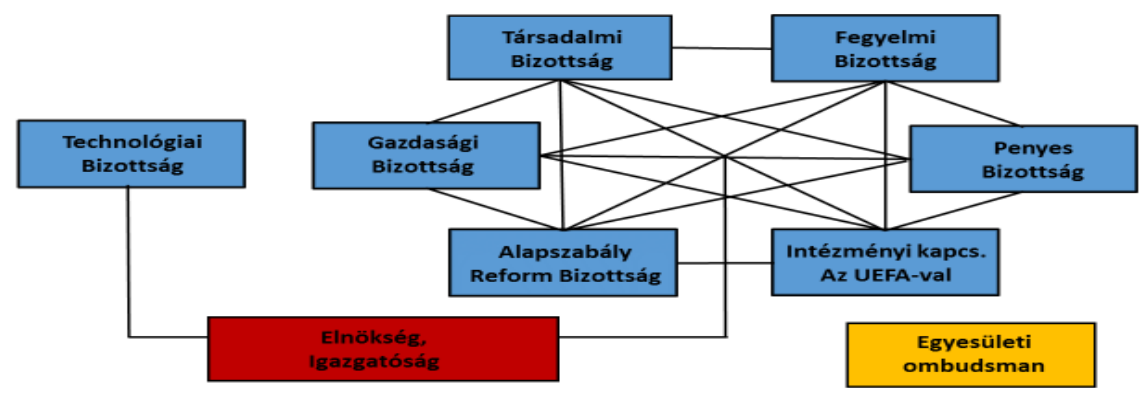

4. ábra: Az FCB végrehajtó szervei, bizottságai

(Forrás: [15]) 
A végrehajtó szervek feladatai:

- A Gazdasági Bizottság egy olyan tanácsadó testület, amely 5 pénzügyekben jártás szakemberből áll, akik közül egyiküknek, igazgatósági tagnak is kell lennie.

- A Társadalmi Bizottság az FC Barcelona képviseletét látja el. Ez a bizottság a klub értékek - a katalán nemzetiség, a demokrácia, a szolidaritás és a társadalmi integritás - képviselője.

- A Fegyelmi Bizottság az egyesületi alapszabályt sértő ügyekben jár el.

- A Penyes Bizottság a hivatalos szurkolói klubokkal (penyakkal) fenntartott kapcsolatokért felelős, a klubértékek őrzője.

- Az UEFA Bizottság feladata az Európai Labdarúgó Szövetséggel való kapcsolattartás.

- Az Alapszabály-reform Bizottság az esetleges szabálymódosítások előkészítésében, háttérmunkálataiban vesz részt.

Ezek a szervek kölcsönös kapcsolatban állnak egymással, amint azt az 4. ábra is mutatja.

A klub működtetésért felelős Technológiai Bizottság a korábbi szervezeti egységektől elkülönülve végzi feladatát.Ezek a szervek az elnökség, az igazgatóság irányítása alatt állnak.

Viszont van egy az elnökségtől, és minden más szervezeti egységtől teljesen független egyszemélyes szerv, az egyesületi ombudsman. Az ombudsman feladata a tagok jogainak védelme, a választások tisztaságának biztosítása. Bármelyik tag fordulhat kérdéssel, kéréssel, vélt vagy valós sérelme kivizsgálása ügyében hozzá. A tisztség viselőjének semmilyen kapcsolata, még rokoni kötődése se lehet az igazgatósággal, ezzel az előírással az egyesületi ügyek független, objektív ügyintézését kívánják biztosítani[16].

A fentiek alapján megállapítható, hogy az FC Barcelona Igazgatóságának, illetve végrehajtószerveinek felépítése funkcionális elveket mutat, azaz a szervezeti egységek bizonyos feladatok (funkciók) ellátására jöttek létre, vagyis a munkamegosztás funkcionális elvre épül. A döntési jogkörök a funkcionális vezetők kezében összpontosulnak. A specializáció eredményeként a vezetők csak az adott szakmai feladatokért felelősek, de akár több szervezeti egységben is. A függelmi viszonyok szabályozása lineáris, azaz vonalbeli elemeket visz a funkcionális struktúrába[17].

A klub működésének másik fontos tanulsága az egyesületi létből fakad. A társadalmi elkötelezettség, az egyesületi megalapozottság egy hatalmas társadalmi bázist biztosít a klubnak, ami aztán fogyasztói keresletben is vissza fog köszönni.

\section{A Real Madrid FC jellemzése}

Akár az előbb bemutatott spanyol klub, a Real Madrid FC is egyesületi formában múködik, és a társadalmi elkötelezettség erre a klubra is igen jellemző. Kiáll a „királyi gárda” a társadalmi integráció, a természeti katasztrófák megelőzése, azok következményeinek enyhítése, - mint UNICEF nagykövet a gyermekek jogainak védelme, az oktatás fejlesztése, és a békés szórakozás ügyéért. Az egyesületi tagok tekintetében jogaik tiszteletben tartását, az átláthatóság biztosítását, a klub értékek védelmét 
hirdetik[18], illetve azt, hogy a stadionokban az erőszakot minimálisra kell csökkenteni, azaz konfrontációnak kizárólag a pályán van létjogosultsága.

Az eddig felsorolt társadalmi vállalások a Real Madrid FC stratégiájában, mint társadalmi stratégiai célok is nevesítve szerepelnek. A klub stratégia a társadalmi pillér mellett még marketing és sport pillérre épül. Ennek a stratégiának a bevezetése Florentino Perez elnökségéhez füződik. A stratégia sikerességéről a 2. ábra is meggyőzhet bennünket, amely szerint a klub 15 év alatt közel megötszörözte bevételét és a korszakban stabilan őrizte vezető pozícióját a Futball "Pénzligában" (Deloitte: a legnagyobb bevétellel rendelkező klubok listája)[19].

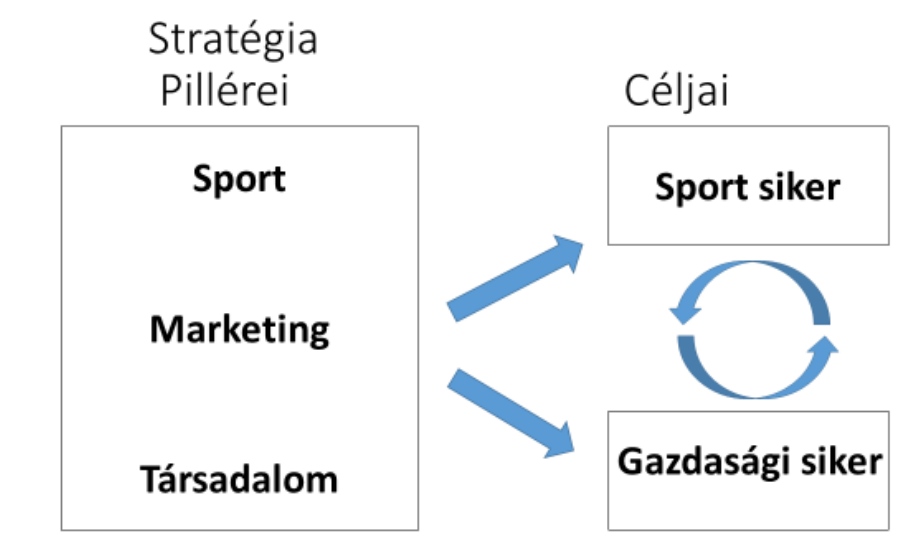

5. ábra: A Real Madrid FC stratégiája Florentino Perez elnöksége alatt

(Forrás: [20]]

Az 5. ábra a stratégia pilléreit és céljait mutatja be. A stratégiai cél mi más lehetne egy labdarúgó klubnál, mint a sport és a gazdasági siker biztosítása. Könnyen belátható, hogy a kettő egymást feltételezi. Ha egy csapat sport sikereket ér el, nő a "fogyasztói kereslet" az általuk kínált sportszolgáltatás iránt, azaz nő a nézőszám a stadionban és a televíziók előtt, nő a csapat, vagy a sztárjátékosok marketingértéke, ami természetesen bevétel növekedésben, azaz gazdasági sikerben tükröződik majd vissza. Különösen jól megfigyelhető a siker e két oldalának összefüggése a Real Madrid esetében, ahol a gazdasági siker sportsikerre történő visszaforgatását sztárjátékosok vásárlásával kísérlik meg.

A sport és gazdasági siker elérésének kettős céljához illeszkedő sportstratégia tehát a megfelelő játékoskeret biztosításával érhető el[21]. Ennek elsődleges forrása a játékospiac, de egyre nő az utánpótlásnevelés jelentősége a Real-nál is.

A stratégia marketing pillére arra épül, hogy új, változatos bevételi forrásokat kell teremteni, tartalomfejlesztéssel a márka minél teljesebb kiaknázására kell törekedni.

Ennek érdekében a klub

- különböző ágazatok piacvezető cégeivel (SIEMENS, PEPSI ALTADIS, AUDI) kötött stratégiai szövetséget, hiszen a cég és a klub márkák közötti szinergia növelheti a márkaértéket;

- új football piacok megnyitása Dél- Kelet Ázsiában, Kínában, Japánban, Dél-Koreában szintén brandépítő jellegü volt; 
- Sok csatornás márka kiaknázásra törekedtek: a focisták image jogait a hirdetési piacon értékesítették,

- kedvezményekre jogosító Real Madrid Fan Card-ot vezettek be,

- online termékértékesítést fejlesztettek ki,

- a RM termékek előállításának (75 gyártó állítja elő a 700 féle RM terméket) és értékesítésének franchise programját dolgozták ki,

- Másrészt a hagyományos sportbevételt biztosító létesítmény kihasználást próbálták maximalizálni:visszavásárolták az addig "külső" kézben lévő stadion szolgáltatásokat, a stadion hirdetési felületét, vendéglátó helyeit,

- sok csatornás jegyértékesítést,

- "alkalmi jegy" árusítást (season ticket) vezettek be,

- VIP páholyokat értékesítettek cégek részére,

- "all inclusive" turisztikai csomagot kínáltak az idegenbeli meccsekre [22].

A Real Madrid Igazgatósága hasonlóan az FC Barcelonáéhoz funkcionális elven épül fel. Az Igazgatók a korábban bemutatott spanyol klubhoz hasonló területekre specializálódtak. Némi különbség csupán a függelmi viszonyok esetében figyelhető meg (6. ábra).

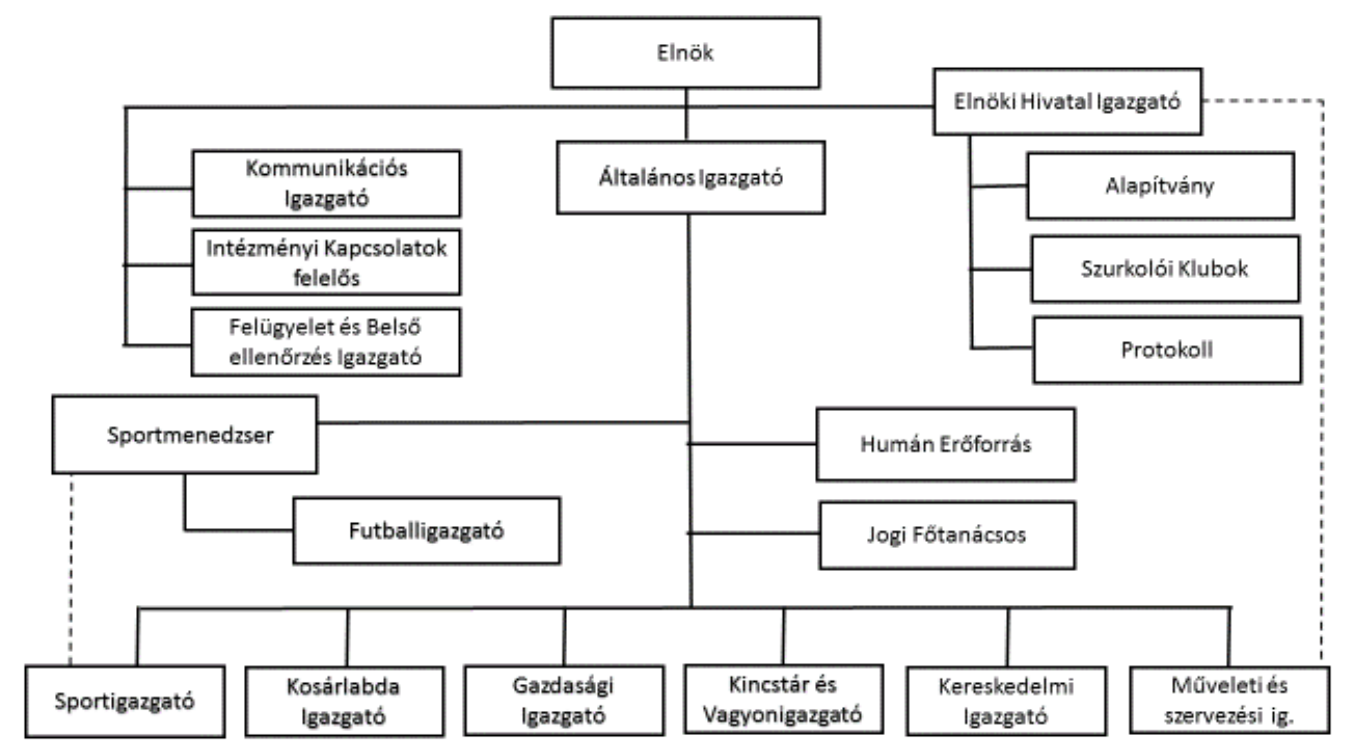

6. ábra: A Real Madrid Igazgatóságának szerkezete

(Forrás: [23])

A Real Madrid jellemzéséből levonható főbb megállapítások:

- a klub a sportszolgáltatások elengedhetetlen velejáróját a sporthoz kapcsolódó bizonytalanságot a márka kiaknázással csökkentette,

- a klub tartalomfejlesztéssel, brandépítéssel olyan fogyasztói körre tett szert, amely a világ minden táján képes azonosulni a klubbal,

- ez az azonosulás a klub bevételek növekedésében realizálódott[24, 25],

- ezek a bevételi források megfelelő anyagi hátteret biztosítottak a játékoskeret kialakításához, 
- ami sportsikerekhez vezetett,

- és ez fenntartja a körforgást, biztosítja a további gazdasági eredményességet.

A RM sikere a fogyasztói kör megtartásától függ, amelynek biztos, a piaci léttől akár függetlenül is meglévő hátterét, az egyesületi létből fakadó társadalmi bázis adja.

A Real Madrid FC stratégiája sikeresen működik. Megvalósításának a kulcstényezője a feladatok ellátásához szükséges szakszemélyzet [26]megléte. Az igazgatóság és a hozzájuk tartozó végrehajtó szervek funkciókra specializálódó felépítést mutatnak.

\section{5. Összegzés}

Hazánkban a sport szervezeti keretei tekintetében megjelent az igény a strukturális formák letisztulására. A sport hazai fejlődése felveti azt a kérdést, hogy mely területeken tartható meg, működhet tovább az egyesületi alapú sportmodell, illetve hol van létjogosultsága a szervezeti felépítésében is üzleti modellnek, esetleg van-e olyan megoldás, amely a kettő ötvözetét valósítja meg. A sport üzleti jellege különösen erősen jelentkezik a professzionalista labdarúgásban. E sportágban világszerte jól megfigyelhető az a strukturális átalakulási folyamat[27, 28], amely a megfelelő vállalkozási forma és szerkezeti felépítés elérésére irányul. E tekintetben célszerü feltérképezni a külhoni jó gyakorlatokat, hogy azok arra érdemes elemei mintaként szolgálhassanak a kialakuló magyar üzleti sportmodell esetében. Jelen cikkemben a nemzetközi élvonalba tartozó, egyesületi keretek közt működő Real Madrid FC és Barcelona FC szervezeti struktúráját mutatom be.

A két spanyol klub vizsgálatának egyértelmű tanúsága, hogy az egyesületi lét, olyan társadalmi bázist biztosíthat, amely a sportszolgáltatások vevőkörének biztos alapját képezheti.

Szervezeti tekintetben megállapítható, hogy elengedhetetlen a feladatokra specializálódott szakszemélyzet megléte, illetve a funkcionálisan felépített szervezeti struktúra.

\section{Hivatkozások}

[1] 1998. évi XXXI. törvény a sportról szóló 1996. évi LXIV. törvény módosításáról (Magyar Jogtár)

[2] É. Bácsné Bába (2016), Futballvállalkozások lehetséges szervezeti formái nemzetközi jó gyakorlatok lapján- esettanulmány a Manchester United FC-ről (az angol modell) VIKEK megjelenés alatt

[3] É. Bácsné Bába (2015), Examination of the organizational frameworks of sports enterprises in the light of good german practices, APSTRACT - APPLIED STUDIES IN AGRIBUSINESS AND COMMERCE (ISSN: 1789-221X), (eISSN: 1789-7874) 9.: (1-2.) pp. 41-46.

[4] Official FC Barcelona Web Site - Barça | FCBarcelona.com - http://www.fcbarcelona.com/ 
[5] Deloitte Sports Business Group, Top of the table, Football Money League (2016), https://www2.deloitte.com/content/dam/Deloitte/uk/Documents/sports-businessgroup/uk-deloitte-sport-football-money-league-2016.pdf

[6] Annual Report of FC Barcelona

[7] Real Madrid CF / Web Oficial - http://www.realmadrid.com

[8] Deloitte Sports Business Group, Top of the table, Football Money League (2016), https://www2.deloitte.com/content/dam/Deloitte/uk/Documents/sports-businessgroup/uk-deloitte-sport-football-money-league-2016.pdf

[9] Annual Report of Real Madrid FC

[10] http://www.eurobarca.hu/hirek/labdarugas/20160313-a-teljes-espai-bar\%C3\%A7aprojekt/17346

A. Pierog, P. Vörös, K. Dajnoki (2014), Civil szervezetek megítélése a munkaerőpiac tükrében, ACTA SCIENTIARUM SOCIALIUM 17:(40)pp. 111-120.

[11] T. Köpeczi-Bócz (2013), A globális gazdaság munkaerő kereslet-kínálatának illeszkedési problémái, In: 9. Magyar Nemzeti és Nemzetközi Lifelong Learning Konferencia: 9th Hungarian National and International Lifelong Learning Conference. Szeged, Magyarország, 2013.04.18-2013.04.19.p.

[12] M.B. Callejo, F.C. Forcadell (2006), Real Madrid Football Club: A new model of business organization for sports clubs in Spain, Global Business and Organizational Excellence 2006/11. 51-64 pp.

[13] Official FC Barcelona Web Site - Barça | FCBarcelona.com - http://www.fcbarcelona.com/

[14] Saját szerkesztés az FC Barcelona official website alapján

[15] Official FC Barcelona Web Site - Barça | FCBarcelona.com - http://www.fcbarcelona.com/

[16] Cs. Berde (2015), Szervezeti formák, In: Bácsn B. É. (szerk.) Sportszervezetek szervezeti felépítése és vezetése, Campus Kiadó, Debrecen

[17] Z. Bács (2012), Értékek a klubépítésben: Values in developing succesfull football club, In: Perényi Szilvia (szerk.) Youth sport and talent management: challenges of the 21th century : II. International Conference on Tourism and Sportmanagement. Debreceni Egyetem Gazdálkodási és Vidékfejlesztési Kar. ISBN:978-615-5183-81-2 68 p.

[18] Deloitte Sports Business Group, Top of the table, Football Money League (2016), https://www2.deloitte.com/content/dam/Deloitte/uk/Documents/sports-businessgroup/uk-deloitte-sport-football-money-league-2016.pdf

[19] M.B. Callejo, F.C. Forcadell (2006), Real Madrid Football Club: A new model of business organization for sports clubs in Spain, Global Business and Organizational Excellence 2006/11. pp. 51-64. 
[20] R. Szőke, Z. Bács, I. Dékán Tné Orbán, T. Dékán (2015), Information content of a sports undertaking's statements serving different purposes - particularly with reference to the player rights, APSTRACT - APPLIED STUDIES IN AGRIBUSINESS AND COMMERCE 2015/1: pp. 119-131.

[21] Real Madrid CF / Web Oficial - http://www.realmadrid.com

[22] Real Madrid CF / Web Oficial - http://www.realmadrid.com

[23] P. Becsky-Nagy, Z. Bács, T. Dékán, R. Szőke (2015), Sports financing, APSTRACT

[24] V. Fenyves (2013), Problems with the application of conventional financial ratios in corporate risk measurement, APPLIED STUDIES IN AGRIBUSINESS AND COMMERCE 13/34. pp. 5-12., 2013.

[25] É. Gergely, E. Dienesné Kovács (2011), Az emberi erőforrás menedzsment egyes területeinek rangsora a szervezetekben, MUNKAÜGYI SZEMLE II.: pp. 43-50.

[26] A. Müller, P. Váczi, Gy. Széles-Kovács (2013), A csapatsportok gazdálkodásának sajátosságai a kosárlabda példáján, In: Tanulmánykötet. A FELSŐOKTATÁS SZEREPE A SPORTBAN, ÉLSPORTBAN ÉS AZ OLIMPIAI MOZGALOMBAN, KÜLÖNÖS TEKINTETTEL A TÁRSASÁGI ADÓBÓL (TAO) TÁMOGATOTT SPORTÁGAK HELYZETÉRE ÉS A TÁMOGATÁSOK HASZNOSÍTÁSÁRA" CÍMÜ KONFERENCIA TANULMÁNY KÖTETE. ISBN 978-963-473-733-9.Kiadja: Debreceni Egyetem Gazdálkodástudományi és Vidékfejlesztési Kar. 131-136.p. Konferencia időpontja: 2013. november 7-8. Debrecen

[27] A. Müller (2009), A legújabb trendek a sportmarketing és menedzsment területén, In: SPORTSZAKEMBER TOVÁBBKÉPZÉSI KONFERENCIA SOROZAT. 69-73.p. Sportszakember továbbképzési konferencia. Eszterházy Károly Főiskola. Magyarország, Eger 